\title{
KINERJA KARYAWAN BERBASIS DISIPLIN DAN MOTIVASI PADA PT. POS INDONESIA (PERSERO) CABANG DEPOK 2
}

\author{
${ }^{1}$ Akbar Aditama Panggarbesi, ${ }^{2 *}$ Ading Sunarto \\ Universitas Pamulang, Tangerang Banten, Indonesia \\ *dosen02153@unpam.ac.id
}

\begin{abstract}
Abstrak
Penelitian ini dilakukan untuk mengetahui pengaruh disiplin dan motivasi Terhadap Kinerja Karyawan Pada PT.Pos Indonesia (persero) cabang depok 2, secara parsial maupun secara simultan. Metode yang digunakan deskriptif kuantitatif menggunakan tehnik random sampling dengan sampel sebanyak 59 responden. Berdasarkan hasil perhitungan analisis regresi berganda diperoleh $\mathrm{Y}=13.998+$ 0,372 X1 + 0,294 X2 , dimana Kinerja Karyawan (Y), Disiplin (X1) dan Motivasi (X2) diuji menggunakan uji $\mathrm{t}$ menunjukkan bahwa kedua variabel independen secara signifikan mempengaruhi Kinerja Karyawan (Y) sebagai variabel dependen. Menggunakan uji F diperoleh bahwa Fhitung = 18.771 dan setelah dikonsultasikan dengan Ftabel pada taraf signifikan 5\% dan n $=(-3)$ menunjukkan Ftabel $=2.77$ yang artinya terdapat pengaruh yang positif dan signifikan antara Disiplin dan Motivasi terhadap Kinerja Karyawan karenafhitung $(18.771)>(2,77)$. Hasil penelitian ini disimpulkan terdapat pengaruh yang positif dan signifikan antara Disiplin (X1) dan Motivasi (X2) secara simultan terhadap Kinerja karyawan (Y).
\end{abstract}

Kata Kunci : Disiplin, Motivasidan Kinerja Karyawan

\section{Abstract}

This research was conducted to determine the effect of discipline and motivation on employee performance at PT.Pos Indonesia (Persero) Depok 2 branch, partially or simultaneously. The method used is descriptive quantitative using random sampling technique with a sample of 59 respondents. Based on the results of the calculation of multiple regression analysis obtained $Y=13,998+0.372 X 1+0.294 X 2$, where Employee Performance (Y), Discipline (X1) and Motivation (X2) were tested using the test showing that the two independent variables significantly affect Employee Performance $(Y)$ as the dependent variable. Using the F test, it is found that Fcount $=18,771$ and after being consulted with Ftable at a significant level of 5\% and $n=(-3)$ shows Ftable $=2.77$, which means that there is a positive and significant influence between Discipline and Motivation on Employee Performance because count (18,771)> (2.77). The results of this study concluded that there was a positive and significant influence between Discipline (X1) and Motivation (X2) simultaneously on employee performance $(Y)$.

Keywords: Discipline, Motivation and Employee Performance

\section{PENDAHULUAN}

Faktor yang sangat penting dalam suatu organisasi, baik organisasi dalam skala besar maupun skala kecil.Karena sumber daya manusia merupakan aset yang paling berharga dan menguntungkan dalam proses produksi. Sebagaimanapun canggihnya suatu teknologi yang telah dimiliki oleh suatu perusahaan tidak akan dapat berjalan dengan baik apabila tidak didukungnya sumber daya manusia yang berkualitas serta memiliki kemampuan, keahlian, keterampilan dan juga kreatifitas disetiap unit atau bagian dari suatu perusahaan tersebut. Manajemen sumber daya manusia merupakan bagian dari manjemen organisasi yang memfokuskan diri pada sumber daya manusia.

Keunggulan dan keberhasilan suatu organisasi sangat bergantung pada kualitas sumber daya manusia yang dimiliki. Manusia lah sebagai penggerak, pembuat rencana, pembuat inovasi dan teknologi di dalam suatu organisasi serta merupakan 
tenaga kerja yang menjadi aset bagi perusahaan dalam meningkatkan kinerjanya.

Karyawan yang menunjukan kinerja yang baik memiliki keinginan untuk meraih kesejahteraan dan keberhasilan dalam pekerjaannya. Kinerja karyawan yang baik dengan semangat kerja yang tinggi akan membantu perusahaan untuk dapat memenuhi target dan memperoleh keuntungan. Sedangkan jika kinerja karyawan menurun dan buruk maka akan merugikan suatu perusahaan. Oleh karena

Tabel 1. Penilaian Kinerja Pegawai (Kualitas) PT. Pos Indonesia (Persero) Depok 2

\begin{tabular}{|c|c|c|c|c|c|c|}
\hline \multirow{2}{*}{$\begin{array}{c}\text { Penilaian } \\
\text { Kinerja }\end{array}$} & \multicolumn{2}{|c|}{ Tahun 2017 } & \multicolumn{2}{c|}{ Tahun 2018 } & \multicolumn{2}{c|}{ Tahun 2019 } \\
\cline { 2 - 7 } & $\begin{array}{c}\text { Jumlah } \\
\text { Orang }\end{array}$ & $\begin{array}{c}\text { Presentase } \\
(\%)\end{array}$ & $\begin{array}{c}\text { Jumlah } \\
\text { Orang }\end{array}$ & $\begin{array}{c}\text { Presentase } \\
(\%)\end{array}$ & $\begin{array}{c}\text { Jumlah } \\
\text { Orang }\end{array}$ & $\begin{array}{c}\text { Presentase } \\
(\%)\end{array}$ \\
\hline Baik & 55 & $37 \%$ & 35 & $24 \%$ & 25 & $17 \%$ \\
\hline Cukup & 40 & $27 \%$ & 55 & $37 \%$ & 60 & $41 \%$ \\
\hline Kurang & 50 & $34 \%$ & 55 & $37 \%$ & 60 & $41 \%$ \\
\hline Total & $\mathbf{1 4 5}$ & $\mathbf{1 0 0 \%}$ & $\mathbf{1 4 5}$ & $\mathbf{1 0 0 \%}$ & $\mathbf{1 4 5}$ & $\mathbf{1 0 0 \%}$ \\
\hline
\end{tabular}

Sumber: HRD PT. Pos Indonesia (Persero) Depok 2

Berdasarkan tabel penilaian kinerja diatas maka dapat disimpulkan ditahun 2017 jumlah pegawai mendapatkan kategori baik sebesar 55 orang atau 37\%, lalu menurun ditahun 2018 yaitu sebesar 35 atau $24 \%$. Sedangkan pegawai yang mendapat kategori cukup menurun ditahun 201855 atau 37\%. Dan pegawai yang mendapatkan kategori kurang meningkat ditahun 2019 yaitu sebesar 60 atau 41\%.

Dalam kinerja karyawan ada beberapa faktor yang dapat mempengaruhi hasil kinerja karyawan, yaitu kedisiplinan karyawan itu sendiri. Suatu organisasi atau perusahaan dituntut memiliki pandangan dan sikap disiplin untuk meningkatkan kinerja pegawai, disiplin kerja merupakan fungsi manajemen sumber daya manusia terpenting dan berkaitan erat pengelola sumber daya bagi suatu perusahaan.

Tabel 2. Tabel Absensi Karyawan PT. Pos Indonesia (Persero) Depok 2 Tahun 2017-2019

\begin{tabular}{|c|c|c|c|c|c|c|c|}
\hline Tahun & $\begin{array}{c}\text { Jumlah } \\
\text { Karyawan }\end{array}$ & Izin & Sakit & $\begin{array}{c}\text { Tanpa } \\
\text { Keterangan }\end{array}$ & Cuti & Total & $\%$ \\
\hline 2017 & 145 & 8 & 17 & 10 & 4 & 39 & $26 \%$ \\
\hline 2018 & 145 & 15 & 10 & 13 & 8 & 46 & $31 \%$ \\
\hline 2019 & 145 & 17 & 8 & 15 & 9 & 49 & $33 \%$ \\
\hline
\end{tabular}

Sumber: HRD PT. Pos Indonesia (Persero) Depok 2

Berdasarkan tabel menunjukan bahwa pada PT. Pos Indonesia (Persero)
Disiplin harus tegakan dalam suatu organisasi, karena tanpa dukungan disiplin kerja yang baik, maka sulit bagi perusahaan atau organisasi untuk mencapai tujuannya. Begitu pula pada PT. Pos Indonesia (Persero) Depok 2, disiplin karyawan menjadi salah satu faktor penentu akan hasil dari kinerja karyawan.

Pada PT. Pos Indonesia disiplin kerja menjadi salah satu penentu dari keberhasilan dari kinerja karyawan. Dan masih banyak karyawan PT. Pos Indonesia yang masih belum disiplin akan pekerjaan. Beberapa faktor penentu tersebut akan penulis jabarkan. Berikut adalah data yang didapatkan dari survei yang dilakukan terhadap karyawan PT. Pos Indonesia, survei ini memiliki beberapa item yang diteliti dalam hal disiplin kerja. 
keterangan 10 orang, dan cut sebesar 4 orang. Jika secara terus menerus sampai tahun 2019 mengalami kenaikan tiap tahunnya apabila kenaikan ini terus berlangsung secara signifikan maka dengan demikian bahwa kedisiplinan kurang baik.

Berdasarkan survei pendahuluan, peneliti mendapatkan informasi mengenai disiplin kerja karyawan terhadap kinerja karyawannya melalui Kepala Bagian Sumber Daya Manusia (SDM) yang menyebutkan bahwa karyawan PT. Pos Indonesia (Persero) Depok 2 HRD masih terdapat karyawan yang tidak disiplin yaitu datang tidak tepat waktu.

Selanjutnya, seseorang yang termotivasi yaitu orang yang melaksanakan subtansial guna menunjang tujuan-tujuan produksi kesatuan kerjanya dan

Tabel 3. Jenis Pemberian Motivasi (Materil dan Non Materil) Pada Karyawan PT. Pos Indonesia (Persero) Depok 2

\begin{tabular}{|c|l|c|}
\hline No & \multicolumn{1}{|c|}{ Pemberian Motivasi (Materil dan Non Materil) } & Keterangan \\
\hline 1 & BPJS dan JKK (Kebutuhan Rasa Aman) & Ada \\
\hline 2 & Pemberian pesangon & Ada \\
\hline 3 & Mengikuti kegiatan lomba antar karyawan. (Kebutuhan Aktualisasi Diri) & Ada \\
\hline 4 & THR, hanya karyawan tetap dan kontrak. (Kebutuhan Fisiologis) & Ada \\
\hline 5 & Upah lembur (Kebutuhan Fisiologis) & Tidak Ada \\
\hline 6 & Uang Makan, apabila jam kerja melebihi jam 17.00. (Kebutuhan Fisiologis) & Ada \\
\hline 7 & Penghargaan atas loyalitas/masa kerja. (Kebutuhan Penghargaan) & Tidak Ada \\
\hline 8 & Bonus Tahunan, Jika Mencapai Target Perusahaan. (Kebutuhan Penghargaan) & Kebijakan \\
\hline
\end{tabular}

Sumber: HRD PT. Pos Indonesia (Persero) Depok 2

Dari tabel di atas dapat di jelaskan bahwa, motivasi langsung yang diberikan perusahaan adalah dengan memberikan BPJS dan Jaminan Kecelakaan Kerja, serta pemberian uang pesangon bagi pegawai yang resign, hanya berdasarkan kebijakan perusahaan dan tidak semua pegawai yang resign mendapatkannya. Dari segi lembur (overtime) perusahaan tidak memberikan upah lembur bagi pegawai yang bekerja melebihi jam kerja operasional. Perusahaan hanya memberikan uang makan lembur yang diberikan kepada karyawan jika melewati jam 17.00 WIB kerja operasional tanpa batas waktu dan tidak ada pemberian uang lembur, artinya berapapun jam kerja lembur yang dilakukan pegawai, intansi hanya memberikan uang makan lembur, hal ini menguntungkan jika pegawai jika hanya melewati jam kerja 0-1 jam, namun perusahaan dimana ia bekerja. Seseorang yang tidak termotivasi hanya memberikan upaya minimum dalam hal bekerja. Berdasarkan observasi awal yang penulis lakukan di PT. Pos Indonesia (Persero) Depok 2 masih terdapat karyawan yang kurang bergairah dalam bekerja, hal ini dikarenakan upah yang diberikan oleh perusahaan tidak sesuai dengan upah minimum regional/kota atau yang telah ditetapkan pemerintah, karyawan juga jarang mendapatkan bonus atas targettarget yang telah dicapainya. Kemudian karyawan juga sulit untuk mendapatkan jenjang karir sehingga posisi karyawan di satu posisi saja tidak dapat naik kepada posisi selanjutnya. merugikan karyawan jika lembur sampai dengan beberapa jam (lebih dari 1 jam).

\section{TINJAUAN PUSTAKA}

Menurut Malayu S.P Hasibuan (2014:193) disiplin kerja merupakan kesadaran dan kesediaan seseorang menaati semua peraturan perusahaan dan norma-norma yang berlaku kesediaan adalah suatu sikap dan tingkah laku dalam melaksanakan peraturan perusahaan, baik yang tertulis maupun tidak tertulis.

Menurut Handoko dalam Arif Yusuf Hamali (2016:213) Disiplin adalah kegiatan manajemen untuk menjalankan standarstandar organisasional.

Faktor selanjutnya yang dapat mempengaruhi kinerja karyawan adalah motivasi. Menurut Zameer, Ali, Nisar dan Amir (2014:297) "motivasi merupakan keinginan untuk melakukan sesuatu yang 
diberikan dan untuk menumbuhkan rasa tanggung jawab".

Seperti yang diungkapkan oleh Menurut Hasibuan (2015:143), Motivasi merupakan pemberian daya penggerak yang menciptakan kegairahan kerja seseorang agar mereka mau bekerja sama, bekerja efektif, dan terintegrasi dengan segala daya upayanya untuk mencapai kepuasan.

Menurut Sutrisno (2015:109) motivasi adalah suatu faktor yang mendorong seseorang untuk melakukan suatu aktifitas tertentu. Oleh karena itu motivasi sering diartikan sebagai faktor pendukung perilaku seseorang.

\section{METODE}

Penelitian ini dilakukan pada bulan Juni 2020 sampai dengan bulan Agustus 2020. Populasi yang dimaksud dalam penelitian ini adalah seluruh karyawan pada PT. Pos Indonesia (Persero) Depok 2 yang akan dijadikan populasi berjumlah 145 orang. Dengan Mengacu pada rumus slovin maka proporsional sampling dalam penelitian ini diperoleh sebagai berikut sampel sejumlah 59

\section{HASIL DAN PEMBAHASAN}

Dalam penelitian ini dapat diketahui bahwa Disiplin (X1) mempunyai rata-rata skor jawaban responden 4,2 atau berada pada kategori baik, hal ini menunjukan bahwa Disiplin di Perusahaan Pos Indonesia (Persero) cabang depok 2 yang dinilai berdasarkan responden memberikan pengaruh terhadap Kinerja Karyawan itu sendiri. Hal tersebut berpengaruh positif dan signifikan sehingga hipotesis yang diajukan dapat diterima.

Pengaruh disiplin (X1) Terhadap Kinerja Karyawan (Y). Analisis dari hasil penelitian menunjukan bahwa secara parsial $\mathrm{H} 1$ diterima atau variabel disiplin (X1) mempunyai pengaruh secara positif dan signifikan terhadap variabel Kinerja Karyawan (Y). Dengan demikian apabila semakin baik tingkat Disiplin (X1) yang diperoleh maka semakin baik meningkat kinerjakaryawan. Hasil hipotesis membuktikan bahwa disiplin berpengaruh positif dan signifikan terhadap kinerja karyawan, dengan didapat hasil uji $t$ variabel disiplin dengan membandingkan $\mathrm{t}$ hitung dengan $\mathrm{t}$ tabel, $\mathrm{T}$ hitung $>\mathrm{T}$ tabel (4.457> 1,672) dengan nilai probabilitas signifikan $0,000<0,005$. Adanya angka signifikan dan positif ini artinya apabila ditingkatkan disiplin maka akan meningkatkan kinerja karyawan pada PT. Pos Indonesia (persero) cabang depok.

Pengaruh Motivasi (X2) Terhadap Kinerja Karyawan (Y)Apabila dari hasil penelitian menunjukkan bahwa secara parsial $\mathrm{H} 2$ diterima atau variabel Motivasi (X2) mempunyai pengaruh positif dan signifikan terhadap variabel Kinerja Karyawan (Y). Dengan demikian apabila semakin baik tingkat motivasi yang diperoleh maka semakin meningkat Kinerja Karyawan. Hasil hipotesis membuktikan bahwa motivasi berpengaruh positif dan signifikan terhadap Kinerja Karyawan, dengan didapat hasil uji t variabel motivasi dengan membandingkan $t$ hitung dengan $t$ tabel, maka diperoleh $\mathrm{t}$ hitung $>\mathrm{t}$ tabel (4.608> 1,672) dengan nilai probability signifikansi $0,000<0,05$. Adanya angka signifikan dan positif ini artinya apa bila motivasi kerja lebih ditingkatkan maka akan meningkatkan Kinerja Karyawan pada PT. Pos Indonesia (persero) cabang Depok 2.

\section{KESIMPULAN}

Berdasarkan hasil perhitungan SPSS 20 Dapat disimpulkan Ha_1diterima yang berarti nilai $t$ hitung $>t$ tabel $(4.457>1,672)$ dari nilai signifikan $0,000<0,005$. Kemudian nilai $R$ Square sebesar 0,258yang artinya variabel disiplin (X1) memberikan kontribusi terhadap variabel kinerja $(\mathrm{Y})$ sebesar 25,8\%,sedangkan sisanya sebesar $74,2 \%$ di pengaruhi variabel lain yang tidak diteliti dalam penelitian ini.

Berdasarkan hasil perhitungan SPSS 20 Dapat disimpulkan Ha_2diterima yang berarti nilai $t$ hitung $>\mathrm{t}$ tabel $(4.608>1,672)$ dari nilai signifikan $0,000<0,00$. Kemudian nilai $R$ square sebesar 0,271 yang artinya variabel motivasi (X2) memberikan 
kontribusi terhadap variabel kinerja (Y) sebesar 27,1\% sedangkan sisanya sebesar $72,9 \%$ di pengaruhi variabel lain yang tidak diteliti dalam penelitian ini.

Berdasarkan hasil hitung SPSS 20 dapat disimpulkan bahwa nilai signifikan $\mathrm{F}$ sebesar 18.771> 2,77 dengan tingkat signifikan $0,000<0,05$ artinya secara simultan maka dapat disimpulkan bahwa hipotesis diterima, artinya variabel disiplin dan motivasi berpengaruh positif dan signifikan secara bersama-sama terhadap kinerja karyawan. Kemudian nilai adjusted $\mathrm{R}$ Square sebesar 0,401 yang artinya secara simultan variabel disiplin (X1) dan motivasi (X2) memberikan kontribusi terhadap variabel kinerja (Y) sebesar 40,1\% sedangkan sisanya $60,9 \%$ di pengaruhi oleh variabel lain yang tidak diteliti dalam penelitian ini.

Sehingga dapat disimpulkan Ha_1 dan Ha_2 diterima berarti terdapat pengaruh X1 danX2terhadap $\mathrm{Y}$ secara bersama.

\section{DAFTAR PUSTAKA}

Affandi, A. (2020). Optimization of MSMEs Empowerment in Facing Competition in the Global Market during the COVID-19 Pandemic Time. Systematic Reviews in Pharmacy, 11(11), 1506-1515.

Aiman, Muhammad Iqbal. 2014. Teknologi Informasi Dan Pendidikan Saling Membutuhkan

Akbar, I. R., \& Wiguna, M. (2020). Hubungan Motivasi Terhadap Prestasi Kerja Guru Pada SMK YAPIA Parung, Kab. Bogor. JENIUS (Jurnal Ilmiah Manajemen Sumber Daya Manusia), 4(1), 61-69.

Akbar, I. R., Prasetiyani, D., \& Nariah, N. (2020). Pengaruh Motivasi Terhadap Kinerja Karyawan Pada Pt. Unggul Abadi Di Jakarta. Jurnal Ekonomi Efektif, 3(1).

AM, E. N., Affandi, A., Udobong, A., \& Sarwani, S. (2020). Implementation of Human Resource Management in the Adaptation Period for New Habits.
International Journal of Educational Administration, Management, and Leadership, 19-26.

Amstrong Dan Baron Dalam Irham Fahmi. 2015. Manajemen Kinerja. Jakarta.

Andi Supangat, (2015), Statistika Dalam

Kajian Deskriptif, Inferensi, Dan Nonparametik, Bandung: Kencana Penada Media Group.

Anggraeni, Dewi. 20014. Pengaruh Motivasi

Dan Disiplin Kerja Terhadap Kinerja Karyawan Pada Pt. Human Karya

Anwar Prabu Mangkunegara. 2015. Sumber

Daya Manusia Perusahaan. Cetakan Kedua Belas. Remaja Rosdakarya:

Bandung

Efendi Riyanto. (2020), The Mediation Of

Work Motivation On The Effects Of

Work Discipline And

Compensation On Performance Batik Msmes Employees In Yogyakarta City, Indonesia. International Journal Of Multicultural And Multireligious Understanding. 7.1.

Erni, \& Kurniawan., 2017., Pengantar Manajemen, Edisi 1, Kencana, Jakarta

Fahmi, Irham. 2016. Manajemen Sumber Daya Manusia Teori Dan Aplikasi. Bandung: Alfabeta

Feriyanto, Andri Dan Shyta, Endang Triana. 2015. Pengantar Manajemen (3 In 1). Kebumen: Mediatera

Ghozali, Imam. (2017). "Aplikasi Analisis Multivariate Dengan Program Spss", Edisi Kelima, Semarang:Badan Penerbit Undip.

Gibson, 2017. Organization, Behavior, Structure \& Process, Edition 10. Boston. Usa.

Hamali, Arif Yusuf. 2016. Pemahaman Sumber Daya Manusia. Yogyakarta: Caps

Hasibuan S.P Malayu. 2014. Manajemen Sumber Daya Manusia. Jakarta: Bumi Aksara.

Hasibuan Saripudin Jasman. (2019). Pengaruh Disiplin Dan Motivasi Terhadap Kinerja Karyawan Pt. Mewah Indah Jaya-Binjai.Jurnal Serambi Mekkah.2.1. 
Herawati, Ni L. M., Et Al. "Pengaruh Pengawasan Pimpinan, Disiplin Dan Kompetensi Pegawai Pada Kinerja Pegawai Inspektorat Kabupaten Tabanan." E-Jurnal Ekonomi Dan Bisnis Universitas Udayana, Vol. 05, 2016

Nurjaya, N., Sunarsi, D., Effendy, A. A., Teriyan, A., \& Gunartin, G. (2021). Pengaruh Etos Kerja Dan Disiplin Kerja Terhadap Kinerja Pegawai Pada Dinas Kehutanan Dan Perkebunan Kota Bogor. JENIUS (Jurnal Ilmiah Manajemen Sumber Daya Manusia), 4(2), 172-184.

Pawar, A., Sudan, K., Satini, S., \& Sunarsi, D. (2020). Organizational Servant Leadership: A Systematic Literature Review for Implications in Business. International Journal of Educational Administration, Management, and Leadership, 1(2), 63-76. Retrieved from

https://harpressid.com/index.php/I JEAMaL/article/view/

Hilman Firmansyah Dan Acep Syamsudin. 2017. Organisasi Dan Manajemen Bisnis. Ombak, Yogyakarta.

Sugiyono (2014). Metode Penelitian Kuantitatif, Kualitatif Dan R\&D. Bandung: Alfabeta

Sunarto, A. (2020). Kinerja Karyawan Berbasis Kepemimpinan Dan Motivasi Pada Pt. Duta Jaya Putra Persada Mining. Jenius (Jurnal Ilmiah Manajemen Sumber Daya Manusia), 3(3), 246-257.

Sunarto, A., Qurbani, D., \& Virby, S. (2020). Pengaruh Kompetensi, Disiplin Kerja Dan Lingkungan Kerja Terhadap Kinerja Pada Pt
Anugrah Bersama Sejahtera

Depok. Jimf (Jurnal Ilmiah

Manajemen Forkamma), 4(1).

Supriyadi, D., et al (2020) Innovation And

Authentic Leadership Of Islamic

University Lectures In Faculty

Pharmacy Faculty: What Is The Role

Of Psychological Capital?. Systematic

Reviews in Pharmacy, 11 (8), 383-393. doi:10.31838/srp.2020.8.56

Suryani, N. L., Sularmi, L., Eka, P. D., Sunarsi, D., \& Maddinsyah, A. (2020). The Analysis of Career Development and Placement of Employee Performance in Pt. Global Means of Transindo in Jakarta. Solid State Technology, 63(6), 1382-1389.

Sutrisno, Edy. 2014. Manajemen Sumber Daya Manusia(Cetakan Ke Tujuh). Jakarta: Kencana Prenada Media Group

Suwatno Dan Donni Juni Priansa. 2016. Manajemen Sdm Dalam Organisasi Publik Dan Bisnis. Bandung: Alfabeta.

Werther, William B, Dan Keith Davis Dalam Tb. Sjafri Mangkuprawira 2016. Human Resources And Personnel Management. Fifth Edition. New York: Mcgraw-Hill, Inc.

Wibowo, 2016. Manajemen Kinerja, Edisi Kelima, Pt.Rajagrafindo Persada Jakarta-14240.

Wilandari, D. F., Sunarsi, D., \& Mas'adi, M. (2021). Pengaruh Penilaian Kerja Terhadap Kinerja Karyawan Pada PT Jaya Mandiri Rekabuana di Cilandak. Jurnal Ekonomi Efektif, 3(2).

Winardi. 2016.Kepemimpinan Dalam Manajemen. Jakarta: Pt. Rineka Cipta. 